\title{
NEGOSIASI IDENTITAS PADA ANAK BERKEBUTUHAN KHUSUS
}

\author{
Oleh : \\ MARIDA SARININGSIH \\ Dosen Prodi Ilmu Komunikasi FIS Universitas Dehasen Bengkulu
}

\begin{abstract}
This study aimed to determine the identity formation process in children with cleft lip in Curup Village Merigi Sakti District Central Bengkulu Regency. The research method was descriptive qualitative method. Informants in this study were 16 people,consists of 3 children with cleft lips, three parents, four neighbors of the children with cleft lips and 3 children who play with them.Data were collected by observation, library research, interview and documentation.The results showed that: (1) children with cleft lips disabilities communication was limited due to interference with their speech;(2) children with with cleft lips disabilitiesobtained theircomfort identities to some people who live with them, but feel uncomfortable with people who mocked their disability; (3) the comfortidentity gained by children with cleft disabilities with people they know; 4) the family ties were considered by children with cleftdisabilities as a bond that support their identity; (5) The support of parents was done through various activities such as buying clothes and take them for a walk; (6) the identity stabilityof children with cleftlips as members of societycould happen when parents were able to understand their needs, but the identity was unsteady when there were those who mocking at them;(7) the provision of affection or special attention weretake them for a walk and buy new clothes that formed the satisfaction as the results of negotiations identity;(8) communications made by children with cleft lips with people around them couldn't run effectively as they need to speak repeatedly to make their communicants understand.
\end{abstract}

\section{Keywords: Identity, Social Acceptance, Cleft Lips, CurupVillage}

\section{PENDAHULUAN}

Anak merupakan generasi penerus cita-cita bangsa, karenanya anak perlu mendapat kesempatan seluas-luasnya untuk tumbuh dan berkembang dengan wajar secara rohani, jasmani maupun sosial. Oleh karena itu negarapun menjamin hak anak yang tertuang dalam undang- undang No.4 Tahun 1979 tentang kesejahteraan anak dalam pasal 2 yang menyatakan bahwa anak berhak atas kesejahteraan, perawatan, asuhan dan bimbingan berdasarkan kasih sayang baik dalam keluarga maupun asuhan khusus dengan wajar. Anak juga berhak atas pelayanan dalam mengembangkan kemampuan dan kehidupan sosialnya untuk menjadi warga Negara yang baik dan berguna serta anak juga berhak atas perlindungan terhadap lingkungan yang dapat membahayakan dan menghambat pertumbuhan dan perkembangan dengan wajar.

Namun tidak semua anak yang hadir dalam kondisi fisik dan mental yang normal, ada sebagian anak yang mengalami hambatan fisik maupun mental yang didapat secara lahiriah maupun gangguan pada saat tumbuh kembang anak sehingga memerlukan perlakuan dan bantuan khusus dalam pemenuhan kebutuhan dan proses tumbuh kembangnya, anak-anak ini disebut sebagai anak yang berkebutuhan khusus.

Pada dasarnya tidak ada seorang anak pun yang ingin dilahirkan ke dunia 
dalam keadaan cacat, baik cacat fisik maupun mental. Demikian pula anak-anak dengan cacat sumbing. Mereka pada dasarnya tidak menginginkan adanya kecacatan fisik pada diri mereka. Pada kenyataannya, cacat sumbing dapat terjadi pada semua kelompok masyarakat, kaya, miskin, berpendidikan atau tidak, bahkan pada kelompok etnis atau budaya di dunia.

Setiap orang tua tentu menginginkan anaknya terlahir dengan sempurna, maka ketika anak dalam keadaan sumbing, orang tua seharusnya tetap bisa menyayangi anak sebagaimana mestinya. Bahkan seharusnya anak-anak cacat sumbing lebih mendapatkan perhatian agar penanganan kelainan yang terjadi pada anak juga tidak mengalami kesalahan. Peranan orang tua dan orang-orang disekitar anak-anak cacat sumbing dalam membantu mencapai perkembangan dan pertumbuhan optimal sangatlah menentukan.

Bagi anak penderita sumbing, penerimaan orang-orang sekitar, terutama orang tua sangat penting untuk membentuk konsep diri yang positif. Sayangnya, fenomena yang ada dimasyarakat, khususnya di Desa Curup Kecamatan Merigi Sakti Kabupaten Bengkulu Tengah adalah kehadiran anak dengan cacat sumbing kurang diterima. Anak-anak sumbing sering mendapat perlakuan kurang baik,seperti ketika marah, orang tua sering mengucapkan "dasar sumbing" yang melukai hati anak tersebut.

Selain itu, perlakuan kurang menyenangkan juga orang-orang yang berada di sekitar tempat tinggal mereka, seperti tetanggadan teman-teman sebaya mereka dirasa kurang menyenangkan. Bibir sumbing sering menjadi bahan olokolokan bagi kebanyakan anggota masyarakat di sekitar anak-anak penderita sumbing ini sehingga mereka pun menjadi malu (minder) dan menutup diri.

Pada kenyataannya, bahasa verbal sebagai media untuk mengungkapkan emosi, pikiran, dan maksud yang digunakan oleh anak- anak cacat sumbing di Desa Curup hampir sama saja dengan anak-anak normal lainnya. Hal ini terbukti saat peneliti meminta anak-anak cacat sumbing dengan umur sekitar Sembilan tahun untuk menulis tentang hobi,cita-cita, dana alamat rumah mereka. Mereka dapat menuliskan hal-hal tersebut sebagaimana anak norma llainnya. Akan tetapi, bahasa lisan yang mereka sampaikan mungkin dapat dikatakan kurang jelas sehingga kebanyakan orang tidak mengerti maksud perkataan mereka. Dengan kata lain,anakanak cacat sumbing ini mengalami kesulitan dalam melakukan komunikasi verbal kepada orang-orang di sekitar mereka.

Meskipun demikian, anak-anak dengan cacat sumbing di Desa Curup dapat melakukan komunikasi non-verbal seperti anak-anak normal lainnya seperti mengerutkan wajah saat marah, bertepuk tangan ketika merasa gembira dan banyak diam saat merasa sedih. Dalam hal ini, banyak orang disekitar mereka agaknya tidak memiliki keinginan untuk memahami bahasa non-verbal yang mereka gunakan dalam keseharian untuk mencapai maksud tertentu sehingga tidak jarang anak-anak ini merasa diabaikan oleh orang-orang disekitar mereka.

Untuk itu perlu adanya penanganan serius dari orang-orang terdekat dan pemerintah agar anak-anak cacat sumbing dapat melakukan aktivitas sosial seperti bersekolah, bermain, bergaul, dan sebagainya. Kemudian dibantu pula oleh semua unsur masyarakat disekitar anakanak sumbing ini yang bertugas melakukan pengawasan langsung terkait kegiatan sehari-hari anak-anak penderita sumbing.

\section{METODE PENELITIAN}

Penelitian ini menggunakan metode deskriptif dengan jenis data kualitatif. Menurut Nazir (2003: 63) metode deskriptif ialah suatu metode dalam meneliti status sekelompok manusia, suatu objek, suatu kondisi, suatu sistem pemikiran ataupun suatu kelas peristiwa 
pada masa sekarang. Metode ini menekankan kepada penjabaran analisis data melalui rangkaian kata yang bukan berupa angka-angka.

Disisi lain mengenai data kualitatif, menurut Bungin (2011:103), data kualitatif dijelaskan kedalam bentuk kalimat serta uraian-uraian bahkan dapat berbentuk cerita pendek. Data kualitatif dapat diartikan pula sebagai data yang berupa tulisan mengenai berbagai fenomena yang diamati.

Keseluruhan informan dalam penelitian ini terbagi dalam dua kelompok, yaitu informan pokok dan informan kunci. Informan pokok merupakan anak-anak penderita sumbing dan orangtua dari anakanak tersebut di Desa Curup Kecamatan Merigi Sakti Kabupaten Bengkulu Tengah. Sementara itu, informan kunci terdiri dari teman bermain dan tetangga dari anakanak cacat sumbing tersebut. Untuk mengumpulkan data, penulis melakukan observasi, studi pustaka, dokumentasi, dan wawancara.

Setelah semua data dikumpulkan, penulis menganalisis data tersebut dengan cara menguraian kata-kata secara objektif sehingga mampu menggambarkan proyek penelitian. Disamping itu,datapun disampaikan kedalam bahasa yang mudah dipahami dan lebih mudah dibaca. Kemudian, hasil uraian tersebut akan diiterpretasikan agar mendapatkan makna yang lebih luas dan relevan. Di samping itu, datapun disampaikan kedalam bahasa yang mudah dipahami dan lebih mudah dibaca. Selanjutnya, hasil uraian tersebut akan diinterpretasikan untuk mendapatkan makna yang lebih luas dan relevan. Teknik analisa data ini dilakukan dengan beberapa tahap menurut Milles dan Hebermen (dalam Moleong, 2002: 248), antara lain: reduksi data, penyajian data, dan penarikan kesimpulan.

\section{HASIL PENELITIAN DAN PEMBAHASAN \\ Teori Negosiasi Identitas Pada Anak Cacat Sumbing}

Teori negosiasi identitas merupakan identitas atau konsep diri yang dipandang sebagai bagian yang menjelaskan proses komunikasi antar budaya. Menurut TingToomey dalam Gudykunts (2002:40-45) terdapat 10 (sepuluh) asumsi teoritis yang merupakan teori negosiasi identitas. Dalam hal ini pula yang peneliti gunakan dalam implementasi teori negosiasi identitas pada anak cacat sumbing di Desa Curup Kecamatan Merigi Sakti Kabupaten Bengkulu Tengah.

1. Dinamika utama dari identitas keanggotaan seseorang dalam suatu kelompok dan identitas pribadi terbentuk melalui komunikasi simbolik dengan orang lainnya.

Seperti pernyataan Pegar saat ditanya tentang kesulitan dalam berkomunikasi dengan teman-teman, ia mengatakan:

"aku idak merasa sulit ngomong kekkawan-kawan aku tu, cak biaso bae cumin mereka suko niru-niru aku ngomong" (wawancara pada tanggal 25 April 2016)

Hal serupa juga disampaikan oleh Eka Sundari yang menyatakan bahwa:

"dikecek sulit idak jugo tapi emang kawan-kawan aku tu agak kurang ngerti kalu aku ngomong tu”. (wawancara pada tanggal 25 April 2016)

Dari hasil wawancara yang diperoleh dari anak-anak cacat sumbing di Desa Curup, mereka merasa tidak kesulitan dalam berkomunikasi dengan orang-orang disekitarnya hanya saja terkadang temanteman mereka suka meniru cara bicara mereka dan ada juga yang tidak mengerti dengan ucapan mereka. Sedangkan dari hasil observasi peneliti, anak-anak cacat sumbing di Desa Curup ini dalam berkomunikasi sedikit kesulitan karena ketika mereka bicara sering diminta untuk diulang-ulang. Gaya bicara anak- anak cacat sumbing ini sering ditiru oleh temantemannya. 
Pernyataan orangtua dari Pegar Riski Haryanto (9) saat ditanya tentang anak mereka yang menderita cacat sumbing mampu berkomunikasi atau berinteraksi dengan kelompok anak-anak normal lainnya, bahwa:

"kami lihat selama ini bisa aja. Orang main, Pegar ikut juga. Kalau ngomong, memang dia agak kurang jelas perlu diulang-ulang. Tapi, anak-anak disekitarsini sudah agak paham kalau anak kami ngomong." (wawancara pada tanggal 25 April 2016)

Sedangkan orang tuadari Abi yaitu BapakYuri dan Ibu Wilna memiliki tanggapan yang hamper sama dengan informan pokok sebelumnya. Yaitu:

"Kadang-kadang main sama kawankawannya yang tinggal sekitar sini. Kalau ngomong emang agak kurang jelas" (wawancara pada tanggal25 April2016)

Dari hasil wawancara peneliti dengan orangtua dari anak-anak cacat sumbing. Orang tua mereka mengatakan bahwa anak mereka mampu berkomunikasi atau berinteraksi dengan anak-anak normal lainnya hanya saja mereka bicara yang kurang jelas dan butuh pengulangan saat bicara. Hasil observasi peneliti juga sama dengan pernyataan dari orangtua dari anak-anak cacat sumbing tersebut.

Sementara tanggapan dari informan kunci yang terdiri dari tetangga anak-anak sumbing dimana yang pertama dari Pak Jarwo (30) mengatakan bahwa:

"Kalau saya mungkin karena sudah biasa bertetangga dengan orang tua sama anak-anak cacat sumbing ini jadi dikit-dikit ngerti omongan mereka. Tapi kadang saya juga ngak dengar apa omongan mereka sama saya" (wawancara pada tanggal 25 April 2016)

Selanjutnya Ibu Astuti (29) menanggapi bahwa:

"Anak-anak ini lucu, sangat ngibur. Trus saya sering ngobrol sama mereka, sama Pegar tu sering. Tapi kadang juga lambat ngerti kata-kata mereka. Dia anaknya sering buat ketawa" (wawancara pada tanggal 25 April 2016)

Istri Pak Dani, yaitu Ibu Serli pun memberi tanggapannya saat diwawancari bahwa:

"saya kira mereka itu baik-baik anaknya, penurut dan ngak nakal. Saya seringng ajak mereka main kerumah dengan anak saya. Ngobrolya nyambung-nyambung aja" (wawancara pada tanggal 25 April 2016)

Di lain pihak, adapun teman-teman bermain anak-anak cacat sumbing juga memberikan tanggapan, seperti Dedi Arkam bahwa:

"akulah lamo bekawan kek Riski samo Abi. Enak maen samonyo beduo. Kami sering pai ke sekolah betigo. Kadang kami jugo main di sungai, mandi kami." (wawancara pada tanggal 25 April 2016)

Adapun Anjani mengatakan soal komunikasi yang mereka lakukan adalah bahwa:

"kami beduo kawan dari TK dulu. Main sering samo- samo, pai samo balik sekolah samo-samo. Kalau buat PR sering kerjokan samo-samo jugo. Aku senang nian samo Eka tu. Dia tu lucu kalau ngomong." (wawancara pada tanggal 25 April 2016).

Dari wawancara yang peneliti lakukan kepada informan kunci, anak-anak yang mengalami cacat sumbing mampu berkomunikasi dengan mereka (informankunci), hanya saja mereka terkadang kurang mengerti dengan apa yang diucapkan anak-anak cacat sumbing tersebut. Masih ada yang menganggap lucu dengan gaya bicara mereka dan terkadang ada yang tertawa saat mendengar cara bicara mereka.

Hasil wawancarapun diperkuat dengan hasil observasi peneliti yang mengindikasikan bahwa anak-anak cacat sumbing mampu berkomunikasi dengan 
orang-orang disekitar mereka, hanya saja anak- anak cacat sumbing mengalami sedikit kesulitan dalam menyampaikan pesan yang hendak disampaikannya, karena kekurangsempurnaan alat bicara mereka untuk menyampaikan kata-kata dalam berkomunikasi dengan oranglain.

2. Orang-orang dalam semua budaya atau kelompok etnis memiliki kebutuhan dasar akan motivasi untuk memperoleh kenyamanan identitas, kepercayaan, keterlibatan, koneksi dan stabilitas baik level identitas berdasarkan individu maupun kelompok.

Dalam semua budaya setiap individu pasti membutuhkan kenyamanan dan keterlibatan dalam kelompok. Begitupun anak-anak cacat sumbing di Desa Curup ini. Berdasarkan hasil wawancara peneliti dengan anak-anak cacat sumbing di Desa Curup, diperoleh informasi dari Pegar sebagai berikut:

"Kalau aku lah tebiaso dengan kawan-kawan jadi meraso nyaman ajo, tapi aku malu kalu lagi kumpul rame-rame idak kek kawan maen aku." (Wawancara pada tanggal 25 April 2016)

Begitu pula halnya pernyataan Eka, namun pernyataan Abi agak berbeda dengan Pegar dan Eka yang menjawab bahwa:

"kadang-kadang aku kesal jugo kawan tu suko niru aku ngomong tapi kalu lagi main aku nyaman ajo". (wawancara pada tanggal 25 April 2016)

Dari hasil wawancara dengan anakanak cacat sumbing diperoleh informasi bahwa mereka merasa nyaman dengan teman-teman bermain mereka (sahabat), namun mereka merasa malu ketika sedang berkumpul dengan banyak orang tanpa sahabat mereka. Terkadang mereka juga kesal dengan teman-teman yang suka meniru cara bicara mereka.

Dari hasil observasi peneliti anakanak cacat sumbing di Desa Curup ini hanya merasa nyaman ketika bermain dengan teman-teman mereka yang bias mengerti mereka, itu terlihat ketika mereka bermain yang terkadang mereka lebih memilih untuk tidak bicara bahkan marah saat teman mereka meniru cara bicara mereka.

Sejalan dengan informasi dari anakanak cacat sumbing tersebut, Bapak Hamro dan Ibu Lindawati yaitu orang tua dari Pegar menuturkan hal sebagai berikut:

"kami raso idak, soalnyo kawannyo main Pegar main jugo". (wawancara pada tanggal 25 April 2016).

Berdasarkan hasil wawancara kepada orang tua anak-anak cacat sumbing dapat disimpulkan bahwa perlakuan anak-anak yang suka meniru-niru cara bicara anak mereka sudah dianggap menjadi kebiasaan anak-anak bermain bersama mereka dan itu bukan menjadi ejekan bagi anak-anak cacat sumbing.

Sedangkan hasil observasi peneliti bahwa anak-anak cacat sumbing pada dasarnya merasa kurang percaya diri ketika teman-teman mereka meniru cara bicara mereka, itu terlihat dari ekspresi mereka ketika teman mereka meniru cara bicara mereka yaitu dengan memilih untuk berdiam diri sampai temannya berhenti meniru mereka bicara.

3. Setiap orang akan cenderung mengalami kenyamanan identitas dalam suatu lingkungan budaya yang familiar baginya dan sebaliknya akan mengalami identitas yang rentan dalam suatu lingkungan yang baru.

Setiap individu dalam menghadapi orang-orang baru disekitar mereka tentu berbeda-beda, termasuk anak-anak cacat sumbing ini. Berdasarkan hasil wawancara yang diperoleh peneliti dengan informan pokok yaitu Pegar, menyatakan:

"kalau mereka ngajak maen baru aku ikut maen". (wawancara pada tanggal 25 April 2016)

Senada dengan pernyataan tersebut Ekayang juga peneliti wawancarai berpendapat: 
"kalau tobotu maen aku ikut jugo". (wawancara pada tanggal 25 April 2016)

Selain itu Abi juga memberikan tanggapan yang hampir sama yaitu sebagai berikut:

"kalau aku senang kenal kek kawan baru tapi tengok dulu kalo dio nakal aku gak maen".(wawancara pada tanggal 25 April 2016)

Dari hasil wawancara dengan anakanak cacat sumbing diperoleh informasi bahwa pada dasarnya mereka suka bermain namun mereka juga melihat suasana lingkungan. Hal yang serupa juga terlihat dari hasil observasi peneliti anak-anak cacat sumbing memang suka bermain namun mereka terlihat menghindar dengan teman yang suka mengganggu mereka.

Selain itu tanggapan dari Bapak Hamro dan Lindawati orangtua dari Pegar yang menyatakan:

"kami raso idak jugo,Cuma anak kami ni idak galak duluan negur samo kawan-kawan yang belum dio kenal".(wawancara pada tanggal 25 April 2016)

Senada dengan pernyataan tersebut, Bapak Eko Suwodo dan Ibu Rofiatul Afia orangtua dari Eka berpendapat:

"sepertinyo agak sulit, soalnyo dio idak mau duluan, harus diajak nian, butuh beradaptasi jugo". (wawancara pada tanggal 25 April 2016)

Sedangkan tanggapan Pak Dani Arbain adalah bahwa:

"kadang-kadang anak cacat ini juga suka malu nian mereka sama orang baru dikenal. Sama orang-orang yang mereka kenal dekat bae mereka tu mau dekat." (wawancara pada tanggal 25April 2016)

Dari hasil wawancara dengan informan kunci dapat disimpulkan bahwa lingkungan yang baru belum memberikan kenyamanan bagi anak- anak cacat sumbing tersebut karena mereka butuh waktu untuk beradaptasi. Begitupun dengan hasil observasi anak-anak cacat sumbing terlihat bermain dengan orang- orang terdekatnya saja yang kemudian dipertegas dengan hasil dokumentasi berikut:

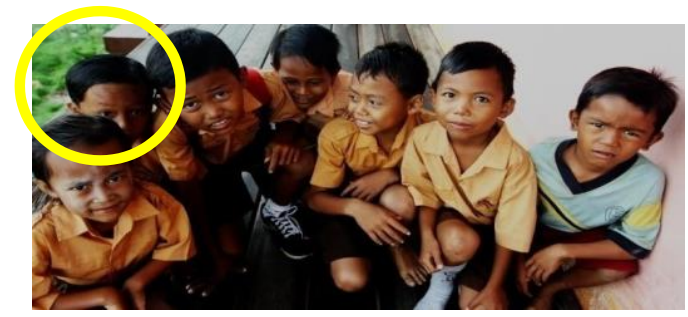

Foto anak dengan lingkaran berwarna kuning diatas (gambar1) adalah Abi, yang tampak sedang berkumpul dengan teman-temannya di sekolah. Dari foto ini, peneliti dapat melihat bahwa Abi memiliki kenyamanan dilingkungan yang familiar baginya bersama orang terdekatnya yaitu teman-teman bermainnya. Dia tampak sangat asyik berkumpul dan bermain dengan temantemannya.

4. Setiap orang cenderung merasakan kepercayaan identitas ketika berkomunikasi dengan orang lain yang budayanya sama atau hampir sama dan sebaliknya kegoyahan identitas manakala berkomunikasi mengenai tema-tema yangterikat oleh regulasi budaya yang berbeda darinya.

Adapun pernyataan informan kunci dan informan pokok pada poin 3(tiga) mempunyai keterkaitan dengan poin 4 (empat) yaitu dari hasil jawaban yang diberikan oleh masing-masing informan tersebut menunjukan bahwa anak-anak cacat sumbing akan merasa minder ketika mereka diperlakukan berbeda, seperti diejek dengan meniru cara bicara mereka ataupun ditertawain ketika mereka berbicara. Seperti tanggapan Pegar Riski ketika ditanya apakah dia merasa minder bergaul dengan teman-temannya yang normal. Dia menanggapi bahwa: 
"aku idak malu, tapi kalau diejek kadang-kadang sedih jugo. Tapi ado jugo kawan aku yang idak nakal." (wawancara pada tanggal 25 April 2016)

Sedangkan Eka Sudari mengatakan bahwa ia sering diejek teman-temannya sehingga membuat dia minder (malu) karena bibirnya sumbing. Adapun pernyataan Eka adalah:

"aku sering diejek-ejek kawan disekolah. Mereka tu nakal-nakal nian. Kadang aku dak mau ngomong lagi samo mereka tu." (wawancara pada tanggal 25 April 2016)

Selain itu, abi pun menanggapi bahwa teman-temannya juga sering mengejek bahwa anak-anak sumbing itu tidak bias juara seperti anak- anak normal lainnya. Abi pun mengatakan bahwa:

"kato sebagian kawan-kawan sekolah tu ado yang ngomong kalau anak-anak sumbing tu dak bisa jadi orang pintar kayak anak-anak yang idak sumbing." (wawancara pada tanggal 25 April 2016)

Para orang tua dari anak-anak sumbing ini pun memberikan tanggapan mereka bahwa anak-anak mereka tetap bias menjalani kehidupan seperti anakanak normal lain. Seperti pernyataan Pak Hamro dan Lindawati:

"memang selama ini anak kami meskipunnyo sumbing bisalah seperti anak-anak normal lain. Tapi kalu diajak main, dio main samo kawan-kawannyo yang kenal." (wawancara pada tanggal 25 April 2016)

Adapun pendapat dari informan kunci yaitu tetangga anak-anak cacat sumbing ini. Informan pertama adalah Bapak Jarwo yang mengatakan bahwa:

"Pegar dan Abi keduonyo anak yang baik. Tapi mungkin mereka kurang beruntung ajo kareno keduonyo sumbing. Kalau anak-anaknyo seperti anak- anak lainlah main samo-samo. Terus kalau endak sesuatu missal ndak mintak minum, anak-anak tu bisa njelaskan." (wawancara pada tanggal 25 April 2016)

Adapun tanggapan dari teman bermain anak-anak cacat sumbing ini, seperti Anjani yang mengatakan bahwa:

"Eka tu maunyo main samo kami ajo. Jarang mau samo anak-anak lain.Eka tu baik, rajin belajar samo ngaji." (wawancara pada tanggal 25 April 2016)

Kemudian pendapat Feraldi yang merupakan teman baik Abi mengatakan bahwa:

"Abi kawan kami sejak di TK. Anaknyo baik nian. Pintar main kelereng samo layang-layang. Kami sering main beduo." (wawancara pada tanggal 25 April 2016)

Hasil wawancara yang diperoleh menunjukan bahwa anak-anak cacat sumbing akan merasa minder ketika mereka diperlakukan berbeda, seperti diejek dengan meniru cara bicara mereka ataupun ditertawain ketika mereka berbicara.

Begitupun dengan hasil observasi penulis anak-anak cacat sumbing merasa lebih percaya diri ketika berkomunikasi dengan orang-orang yang mengerti keadaan mereka seperti orangtua, teman bermain (sahabat). Merekapun akan merasa goyah ketika mereka diperlakukan berbeda seperti ditertawain ketika mereka berbicara ataupun meniru cara bicara mereka.

5. Seseorang akan cenderung merasa menjadi bagian dari kelompok bila identitas keanggotaan dari kelompok yang diharapkan member respon yang positif. Sebaliknya akan merasa berbeda/asing saat identitas keanggotaan kelompok yang diinginkan member respon yang negatif.

Setiap individu mengharapkan respon yang positif dalam identitas keanggotaan dari kelompok, begitu juga dengan anak-anak cacat sumbing di Desa Curup ini. Berdasarkan hasil wawancara 
yang diperoleh peneliti dengan informan pokok yaitu Pegar, menyatakan:

"apo tobotu galak niru-niru aku ngomong".(wawancara pada tanggal 25 April 2016)

Senada dengan pernyataan tersebut Eka yang juga peneliti wawancarai berpendapat:

"kadang-kadang ado jugo kawan yang sengajo niru aku ngomong, tapi bagi aku biaso bae klak dio jugo bosan sendiri". (wawancara pada tanggal 25 April 2016)

Dari hasil wawancara dengan anakanak cacat sumbing dapat disimpulkan bahwa teman-teman mereka memberikan respon yang negative dengan meniru cara bicara mereka. Hasil dari observasi peneliti terlihat anak-anak normal sering meniru cara bicara mereka

Peneliti juga mewawancarai masingmasing orang tua anak-anak cacat sumbing tersebut, diantaranya dengan Bapak Hamro dan Lindawati orangtua dari Pegar yang menyatakan:

"biaso bae, kawan nyo maen Pegar maen jugo memang kalu bicara kawan-kawan nyo sering minta diulang- ulang". (wawancara pada tanggal 25 April 2016)

Namun pernyataan Bapak Yuri dan IbuWilna orangtua dari Abi sedikit berbeda, mereka berpendapat:

"selama ini orang-orang di lingkungan ini baik-baik, gak ada yang nyakiti anak kami”. (wawancarapada tanggal 25 April 2016)

Adapun tanggapan dari Bapak Jarwo sebagai salah satu tetangga dari anak-anak cacat sumbing ini, adalah bahwa:

"ngomong soal identitas, sudah jelas kalau anak-anak sumbing ini ngak jauh beda dengan anak-anak yang ngak sumbing. Tidak ada yangbedabedain. Cuma kadang-kadang ada anak-anak yang suka usil ganggu anak-anak sumbing ini." (wawancara pada tanggal 25 April 2016)
Di lain pihak seperti teman-teman bermain anak-anak sumbing, seperti informan pertama adalah Dedi Arkam yang mengatakan bahwa:

"kami dak pernah ganggu Pegar atau Abi. Cuma anak-anak disekolah banyak ngejek tobo beduo tu." (wawancara pada tanggal 25 April 2016)

Kemudian, Anjani mengatakan bahwa:

"Eka sering diejek sama temanteman disekolah. Kadang-kadang nangisnyo." (wawancara pada tanggal 25 April 2016)

Dari hasil wawancara dengan informan kunci dan informan pokok dapat dijelaskan bahwa respon negatif berupa ejekan dari teman-teman mereka akan tetapi disisi lain identitas dari keanggotaan anak-anak cacat sumbing yang khususnya berada di Desa Curup ini belum begitu diterima karena masih ada anggota masyarakat yang bertindak diskriminatif atau mengganggu anak-anak cacat sumbing tersebut.

Hasil observasi pun menunjukan bahwa masih ada orang yang suka mengejek anak-anak cacat sumbing di Desa Curup ini. Ejekan itu berupa meniruniru cara bicara mereka ataupun sengaja menertawain gaya bicara mereka.

6. Seseorang akan mengharapkan koneksi antar pribadi melalui kedekatan relasi yang meaningfull (misalnya dalam situasi yang mendukung persahabatan yang akrab) dan sebaliknya akan mengalami otonomi identitas saat mereka menghadapi relasi separatis/terpisah.

Setiap individu pasti mengharapkan koneksi dan motivasi antar pribadi. Begitupun dengan anak-anak cacat sumbing di Desa Curup ini. Berdasarkan hasil wawancara peneliti dengan anakanak cacat sumbing di Desa Curup, diperoleh informasi dari Pegar sebagai berikut:
"sayang galo orang kek aku ko,apolagi emak kek bak sering belikan baju baru, jalan-jalan aku 
senang nian" (Wawancara pada tanggal 25 April 2016).

Begitu pula halnya pernyataan Eka, namun pernyataan Abi agak berbeda dengan Pegar dan Eka yang menjawab bahwa:

"aku senang kek bak aku, bak sering ngajak aku jalan- jalan tapi emak aku galak marah aku kadangan tu”. (wawancara pada tanggal 25 April 2016)

Sejalan dengan informasi dari anakanak cacat sumbing tersebut, Bapak Hamro dan Ibu Lindawati yaitu orang tua dari Pegar menuturkan hal sebagai berikut:

"selamo ini terlihat baek-baek ajo tapi kami selaku orang tuo terus memotivasi dio supayo dio idak meraso minder dengan kawankawannyo. Misalnyo kami belikan baju baru, kami ajak kepesta atau hajatan". (wawancara pada tanggal 25 April 2016).

Kesaksian pun datang dari temanteman bermain anak-anak sumbing ini seperti Dedi yang menyatakan bahwa:

"Pegar tu sering main samo kami. Dio kami tengok di sekolah kadang belago kareno anak-anak tu sering ngejek dio sumbing." (wawancara pada tanggal 25April 2016)

Sementara itu, Anjani mengatakan bahwa:

"kami kawan nian samo Eka.

Kemano-mano kami beduo, terus main masak-masakan, main boneka. Kalau samo anak yang lain dio malu, takut diejek katonyo." (wawancara pada tanggal 25 April 2016)

Feraldi, teman dari Abi,menanggapi bahwa:

"Abi suko main sendiri disekolah, paling mainnyo di rumah samo kami samo kawan-kawan yang lain." (wawancara pada tanggal 25 April 2016)

Dari hasil wawancara dengan masing-masing informan tersebut menunjukan adanya dukungan dari orangorang terdekat saja,yaitu orang tua mereka dengan membelikan baju baru dan mengajak jalan-jalan. Sedangkan dilingkungan luar rumah mereka hanya mendapatkan dukungan dari teman dekatnya saja yang selalu paham dengan kekurangan mereka. Hasil observasi yang diperoleh peneliti yaitu anak-anak cacat sumbing ini hanya memperoleh dukungan dari orang-orang terdekat mereka saja seperti, orangtua mereka dan sahabat mereka.

7. Orang akan memperoleh kestabilan identitas dalam situasi budaya yang dapat diprediksi dan akan menemukan perubahan identitas atau goncang dalam situasi-situasi budaya yang tidak diprediksi sebelumnya.

Terkadang setiap individu akan memperoleh kestabilan dalam diri yang dapat diprediksi sebelumnya, namun ada pula perubahan identitas yang tidak dapat diprediksi. Berdasarkan hasil wawancara yang diperoleh peneliti dengan informan kunci yaitu Pegar, menyatakan:

"kalau bak kek mak aku saying kek aku tapi kalu kawan-kawan aku sering ketawoin aku ngomong, kadang kesal jugo aku".(wawancara pada tanggal 25 April 2016)

Senada dengan pernyataan tersebut Eka yang juga peneliti wawancarai berpendapat:

"emak kek bak aku baek, nyo sayang kek aku tapi kawan aku sering ngucak aku, kadang aku nangis mako tobotu brenti". (wawancara pada tanggal 25April 2016)

Selain itu Abi juga memberikan tanggapan yang hampir sama yaitu sebagai berikut:

"idak ado kawan aku dak berani ganggu aku, kalunyo ngucak aku tinju".(wawancara pada tanggal 25 April 2016)

Dari hasil wawancara dengan anakanak cacat sumbing dapat disimpulkan bahwa orang tua mereka sayang dengan mereka namun mereka sering diganggu teman-teman mereka yang terkadang bisa 
menimbulkan kekesalan mereka seperti marah atau menangis.

Adapun hasil observasi peneliti, anak-anak cacat sumbing di Desa Curup ini terkadang menangis atau marah ketika mereka bermain, karena teman-teman mereka suka bercanda yang berlebihan dengan menyinggung kekurang sempurnaan mereka. Bapak Hamro dan Lindawati orang tua dari Pegar yang menyatakan:

"kalau aku tengok nyaman-nyaman bae apolaginyo sering maen kek kawan-kawan sekitar sini tapi kadang-kadang ado anak-anak yang iseng niru-niru dio ngomong". (wawancara pada tanggal 25 April 2016)

Senada dengan pernyataan tersebut, Bapak Eko Suwodo dan Ibu Rofiatul Afia orangtua dari Eka berpendapat:

"kalu orang-orang dekat rumah ni baek-baek ajo dakdo yang ngucak anak kami tapi ado jugo anak- anak yang nakal, biaso saling kucak". (wawancara pada tanggal 25 April 2016)

Sejalan dengan pernyataan tersebut, Bapak Yuri dan Ibu Wilna orangtua dari Abi berpendapat:

"kadang-kadang dio bilang senang tinggal disini, tapi kadang-kadang bosen maklum anak-anak". (wawancara pada tanggal 25 April 2016)

Tanggapan juga datang dari tetangga anak-anak sumbing ini. Seperti Bapak Jarwo yang mengatakan bahwa:

"sayo liat anak-anak sumbing seperti anak tetangga sayo, Pegar, jugo aktif. Maen samo anak-anak lain. Tapi kadang-kadang banyak anak menjahili dio. Kadang nah diolah nangis balik." (wawancara pada tanggal 25 April 2016)

Informan berikutnya adalah temanteman bermain anak-anak sumbing. Informan pertama adalah Dedi yang mengatakan bahwa:
"Pegar samo Abi suko jugo diganggu anak-anak dari desa lain. Di sekolah jugo galak. Kadang beduo tu belago kek anak-anak desa lain tu. Kami salah idak sering dikucaknyo." (wawancara tanggal 25 April 2016)

Selain itu, Feraldi memberikan tanggapannya bahwa:

"Anak-anak desa lain tu kadang ganggu Abi. Kami idak salah kadang diejek-ejeknyo. Kadang tibo-tibo ajo,ngecek Abi sumbing" (wawancara tanggal 25 April 2016)

Dapat dijelaskan bahwa orang tua dari anak-anak cacat sumbing dianggap paling mengerti sehingga anak-anak cacat sumbing memperoleh kestabilan identitas dalam situasi dirumah. Sebaliknya mereka akan merasa goncang ketika berbicara dengan orang lain yang suka mengganggu atau meniru cara bicara mereka sehingga membuat perubahan identitas, seperti marah dan menangis.

8. Dimensi budaya, personal dan keragaman situasi mempengaruhi makna, interpretasi dan penilaian terhadap tematema atau identitas tersebut.

Setiap budaya atau kebiasaan mempengaruh iidentitas anak-anak cacat sumbing di Desa Curup Kecamatan Merigi Sakti Kabupaten Bengkulu Tengah. Berdasarkan hasil wawancara yang diperoleh peneliti dengan informan pokok yaitu pegar, menyatakan:

"Kalau aku sering ikut lari karung pas acara 17Agustus."(wawancara pada tanggal 25 April 2016)

Senada dengan pernyataan tersebut Eka yang juga peneliti wawancarai berpendapat:

"Sering jugo pas acara ulang tahun kawan, aku disuruh jogged kalu 17 Agustus aku suko ikut lomba masukin pensil kebotol". (wawancara pada tanggal 25 April 2016)

Selain itu Abi juga memberikan tanggapan yang sama yaitu sebagai berikut: 
"ikut lomba lari karung aku,tapi aku senang nian nonton panjat pinang". (wawancara pada tanggal 25 April 2016)

Bapak Hamro dan Lindawati orang tua dari Pegar yang menyatakan:

"kalau anak kami samo seperti anak normal lainnyo, 17 Agustus suko ikut-ikut perlombaan, sore anakanak kemasjid belajar ngaji dio ikut jugo". (wawancara pada tanggal 25 April 2016)

Adapun penjelasan yang diberikan Bapak Jarwo terhadap anak- anak sumbing dalam lingkungan mereka. Tanggapan Bapak Jarwo adalah bahwa:

"anak-anak sumbing ini sering diikutsertakan dalam perlombaan terutama 17 agustus-an. Mereka selalu diajak. Kadang-kadang anakanak tu lomba melukis samo menari kalu yang cewekkan." (wawancara pada tanggal 25 April 2016)

Adapun Ibu Astuti mengatakan bahwa:

"kita sebagai warga disiko idak ada yang namonyo tindakan diskriminatif. Segalo anak orang ko samo. Kalau ado acara seperti lomba 17Agustus-an, anak-anak sumbing tu harus diikutkan." (wawancara pada tanggal 25 April 2016)

Tanggapanpun juga datang dari Bapak Dani suami dari Ibu Serli, yang mengatakan bahwa:

"anak-anak sumbing tu diajak kalau ado acara lomba bagi anak-anak, tapi kadang anak-anak tu malu." (wawancara pada tanggal 25 April 2016)

Adapun pihak lain yang membantu peneliti dalam mengambil data penelitian adalah teman-teman bermain anak-anak cacat sumbing. Informan pertama adalah anak bernama Dedi, yang mengatakan bahwa:

"kami sering main lomba balap karung samo Pegar samo Abi. Beduo tu cepat pulo. Tapi sekalikalinyo ikut. Katonyo malu, kelak banyak orang gelak-gelakkan nyo beduo." (waancara pada tanggal 25 April 2016)

Tanggapan selanjutnya dating dari teman dekat Eka Sudari yaitu Anjani, yang menyatakan bahwa:

"Eka anaknyo pemalu nian. Terus kami ajak terus. Kadangnyo endak tapi kadang idak mau. Takut dikai sumbing, kami idak pernah ngomongnyo gitu. Tapi anak-anak dari desa lain. Memang nakal-nakal nian tobo tu." (wawancara pada tanggal 25 April 2016)

Sama halnya dengan Dedi dan Anjani, Feraldi mengatakan bahwa:

"Pegar samo Abi sering diganggu pas lomba tu, kayak lomba balap karung samo panjat pinang. Anakanak di sekolahan kami sering ngejek-ngejek sumbing." (wawancara pada tanggal 25 April 2016)

Dari hasil obervasi dan hasil wawancara dengan masing-masing informan dapat disimpulkan bahwa budaya atau kebiasaan dari anak-anak cacat sumbing tersebut dapat mempengaruhi makna dan penilaian terhadap identitas mereka. Anak-anak cacat sumbing tersebut terlibat dalam kegiatan masyarakat sama seperti anak-anak normal lainnya. Terlihat dari kegiatan mereka yang ikut serta dalam kegiatan masyarakat yaitu ikut perlombaan. Keragaman tersebut dapat merubah isu-isu identitas mereka kalau anak cacat sumbing memiliki keterbatasan atau ketidakmampuan mereka.

9. Kepuasan hasil dari negosiasi identitas meliputi rasa dimengerti, dihargai dan didukung.

Dari hasil wawancara pada poin-poin diatas anak-anak cacat sumbing di Desa Curup memberikan tanggapan bahwa orang tuanya paling mengerti, paham dan mendukung dirinya. Itu terlihat dari hasil wawancara dipoin 6 (enam), kepuasan hasil negosiasi identitas anak-anak cacat sumbing ini berupa kasih sayang dan 
perhatian khusus dari orang- orang terdekat mereka terutama orangtua.

Berdasarkan hasil wawancara peneliti dengan anak-anak cacat sumbing di Desa Curup, diperoleh informasi dari Pegar sebagai berikut:

"emak kek bak sering belikan baju baru ,jalan-jalan aku senang nian" (Wawancara pada tanggal 25 April 2016)

Begitu pula halnya pernyataan Eka, namun pernyataan Abi agak berbeda dengan Pegar dan Eka yang menjawab bahwa:

"bak sering ngajak aku jalan-jalan tapi emak aku galak marah aku kadangan tu".(wawancara pada tanggal 25 April 2016)

Sejalan dengan informasi dari anakanak cacat sumbing tersebut, Bapak Hamro dan Ibu Lindawati yaitu orang tua dari Pegar menuturkan hal sebagai berikut:

"tentunyo sebagai orangtuo kami terus memotivasi dio supayo dio idak meraso minder dengan kawankawannyo. Misalnyo kami belikan baju baru, kami ajak kepesta atau hajatan".'(wawancara pada tanggal 25 April 2016).

Senada dengan pernyataan tersebut, Bapak Eko Suwodo dan Ibu Rofiatul Afia berpendapat.

"anak kami rasonyo biaso-biaso ajo, dio sering main kek kawankawannyo".(wawancara pada tanggal 25 April 2016)

Pendapat yang sama juga diungkapkan oleh BapakYuri dan Ibu Wilna selaku orangtua dari Abi:

"idak pulo bepengaruh nian kalu kami tengok sekarang ni tapi kami selaku orangtuonyo terus kasih motivasi dio supayo dio idak meraso minder" (wawancara pada tanggal 25 April 2016)

Kesaksian pun datang dari temanteman bermain anak-anak sumbing ini seperti Dedi yang menyatakan bahwa:

"Pegar tu sering main samo kami. Dio kami tengok di sekolah kadang belago kareno anak-anak tu sering ngejek dio sumbing." (wawancara pada tanggal 25April 2016)

Sementara itu, Anjani mengatakan bahwa:

"kami kawan nian samo Eka.

Kemano-mano kami beduo, terus main masak-masakan, main boneka. Kalau samo anak yang lain dio malu, takut diejek katonyo." (wawancara pada tanggal 25 April 2016)

Feraldi, teman dari Abi,menanggapi bahwa:

"Abi paling mainnyo suko sendiri disekolah, dirumah samo kami samo kawan-kawan yang lain." (wawancara pada tanggal 25 April 2016)

Seperti pernyataan pegar bahwa orang tuanya sering membelikan baju baru dan mengajak jalan-jalan. Pada contoh ini, membelikan baju baru dan mengajak jalanjalan merupakan suatu perwujudan dukungan dari orang-orang terdekat mereka, sehingga mereka memahami bahwa identitas sebagai anggota keluarga sangat diterima.

10. Komunikasi antarbudaya yang mindful menekankan pentingnya penyatuan pengetahuan antar budaya, motivasi dan keterampilan untuk dapat berkomunikasi dengan memuaskan, tepat dan efektif.

Dalam hal ini, anak-anak cacat sumbing yang memang memiliki keterbatasan dalam berbicara atau menyampaikan pesan tetapi dapat berupaya optimal untuk berkomunikasi dengan baik. Berdasarkan hasil wawancara yang diperoleh peneliti dengan anak-anak cacat sumbing yaitu pegar, menyatakan:

"semua orang hamper ngerti, tapi
mereka minta diulang-ulang.
Maunya dioperasi biar bisa
ngomong normal". (wawancara
pada tanggal 25 April 2016)

Selain itu Abi juga memberikan tanggapan yang sama yaitu sebagai berikut: 
"kadang gak ngerti, mereka minta diulang biar ngerti".(wawancara pada tanggal 25 April 2016)

Dari hasil wawancara dengan anakanak cacat sumbing di Desa Curup diperoleh informasi bahwa ketika mereka bicara dengan orang- orang disekitar mereka butuh pengulangan. Hasil observasi pun juga demikian, ketika peneliti mewawancarai mereka peneliti sering meminta mereka mengulangi setiap ucapan mereka sampai peneliti mengerti dari maksud yang disampaikan mereka.

Sementara itu bapak Hamro dan ibu Lindawati orang tua dari Pegar yang menyatakan:

"kalau sama orang dewasa iyo biasoajo, kadang- kadang kawan maennyotulah suko iseng, kalu lagi diajak ngomong nyambung Cuma pengucapannyo tu harus diulangulang supayo tepat". (wawancara pada tanggal 25 April 2016)

Senada dengan pernyataan tersebut, Bapak Eko Suwodo dan Ibu Rofiatul Afia orangtua dari Eka berpendapat:

"kami tengok biaso ajo, pengucapan nyo tu yang kurang jelas. Tapi kalulah biaso paham jugo kito kek ucapannyo tu". (wawancara pada tanggal 25 April2016)

Sejalan dengan pernyataan tersebut, Bapak Yuri dan Ibu Wilna orangtua dari Abi berpendapat:

"biaso ajo, samo ajo kek anak-anak normal lainnyo cumin kalu baru kenal kek Abi mungkin orang belum paham nian kek ucapannyo, tapi kalulah biaso kito paham jugo". (wawancara pada tanggal 25 April 2016)

Adapun pendapat informan kunci yaitu tetangga anak-anak cacat sumbing ini mengatakan,seperti Pak Jarwo bahwa:

"kalau menurut sayo, anak-anak cacat ini kapan berkomunikasi sulit dimengerti bagi orang lain, terlebih orang baru. Butuh diulang apa yang dio omongkan. Jadi kita sulit pahamlah intinya. Kecuali sudah biasa ngobrol dengan anakanak ini." (wawancara pada tanggal 25 April 2016)

Sedangkan Ibu Astuti mengatakan bahwa: "samo dengan bapak juga, saya cukup sulit untuk mengerti kapan ngomong dengan anak-anak sumbing ini. Kalau idak terbiaso mungkin jugo payahnangkap maksud mereka. apalagi orang baru." (wawancara pada tanggal 25 April 2016)

Pendapat pun datang dari teman bermain anak-anak cacat ini, seperti Dedi Arkam yang mengatakan bahwa:

"kadang Riski ngomong jugo idak jelas.Tapi kadang kami iyo-iyokan ajo." (wawancara pada tanggal 25 April 2016)

Selanjutnya adalah teman Eka yaitu Anjani yang menanggapi bahwa:

"Eka tu anaknya baik. Kalau ngomong tu pelan nian, tapi kami ngerti kok. Tapi kadang-kadang kurang ngerti karena ngak jelas. "(wawancara pada tanggal 25 April 2016)

Dari hasil observasi dan wawancara dengan informan kunci dapat disimpulkan bahwa orang-orang disekitar mereka mampu menerima hal- hal yang dibicarakan oleh anak-anak cacat sumbing namun butuh waktu dan konfirmasi yang terkadang berulang-ulang.

Dalam hal ini, komunikasi antara anak-anak cacat sumbing dengan orangorang disekitar mereka belum dapat berjalan secara memuaskan, tepat dan efektif. Memuaskan dalam pengertian bahwa komunikasi tersebut dapat terlaksana seperti anak-anak normal berkomunikasi, namun hal tersebut membutuhkan waktu yang cukup lama. Atau seperti pernyataan Pegar bahwa anakanak sumbing dapat melakukan operasi bibir agar dapat berbicara dengan baik.

\section{PEMBAHASAN}

Teori Negosiasi Identitas Pada Anak Cacat Sumbing 
Pada penelitian ini, implementasi dimaksudkan sebagai langkah menerapkan teori negosiasi identitas agar mengetahui lebih jauh komunikasi yang terjadi diantara orang-orang yang berbeda latarbelakang. Perbedaan latarbelakang tersebut terjadi dalam ruang lingkup antara anak-anak cacat sumbing dengan orangorang yang hidup berdampingan dengan mereka di Desa Curup Kecamatan Merigi Sakti Kabupaten Bengkulu Tengah. Seperti 10 asumsi teoritis yang merupakan inti dari teori negosiasi identitas yang dikemukakan oleh Ting Toomey dalam Gudykunts (2002:40-45), berikut adalah analisa peneliti terhadap realita yang ditemukan dilapangan berdasarkan hasil wawancara, observasi dan dokumentasi terkait dengan anak-anak cacat sumbing yang ada di Desa Curup Kecamatan Merigi Sakti Kabupaten Bengkulu Tengah.

1. Dinamika utama dari identitas keanggotaan seseorang dalam suatu kelompok dan identitas pribadi terbentuk melalui komunikasi simbolik dengan orang lain.

Dalam hal ini, sifat dinamis terkait dengan kemampuan anak- anak cacat sumbing beradaptasi dengan orang-orang disekitarnya sehingga munculnya suatu komunikasi. Kemampuan anak-anak cacat sumbing di Desa Curup ini dapat dilihat dari kesaksian orang yang paling dekat dengan mereka, yaitu orang tua mereka. Dinamika anak- anak cacat sumbing dalam beradaptasi mungkin dapat dinilai sama halnya dengan anak-anak atau orang-orang normal lainnya, hanya saja anak-anak cacat sumbing mengalami sedikit kesulitan karena kekurang sempurnaan alat bicara mereka dalam menyampaikan kata-kata dalam berkomunikasi dengan orang lain. Masih ditemukan sebagian dari teman bermain mereka yang meniru-niru gaya bicara mereka. Kekurangan pada alat bicara bagi anak penderita sumbing bisa kita pahami bahwa mereka mengalami sedikit kesulitan dalam berkomunikasi. Sehingga dapat dikatakan bahwa dinamika dilihat dari komunikasi simbolik atau yang bisa diartikan bahasa-bahasa simbol yang bias ditiru oleh teman-teman sepermainan mereka, sehingga membentuk simbolsimbol yang bisa dipahami bersama teman dan anak-anak cacat sumbing itu sendiri.

2. Orang-orang dalam semua budaya atau kelompok etnis mempunyai kebutuhan dasar akan dorongan dalam mendapatkan kenyamanan, kepercayaan, keterlibatan, koneksi dan stabilitas berdasarkan individu dan kelompok.

Pernyataan dari anak-anak cacat sumbing di Desa Curup pada dasarnya memperoleh kenyamanan identitas karena sudah terbiasa dengan teman-teman bermain mereka atau lingkungan mereka. Teman bermain anak-anak cacat sumbing ini dapat berasal dari lingkungan sekitar tempat mereka tinggal dan lingkungan sekitar sekolah.

Walaupun terkadang ada perasaan kurang nyaman ketika ada teman-teman mereka meniru cara bicara mereka. Anakanak inipun menjadi bahan ejekan temanteman dilingkungan bermain mereka baik di rumah maupun di sekolah. Adapun pernyataan orangtua dari anak-anak cacat sumbing pun menunjukkan bahwa di satu sisi, kenyamanan dalam identitas (cacat sumbing) tidak membuat mereka merasa minder yang berlebihan atau kepercayaan dalam diri mereka sama dengan anak-anak normal lainya. Tetapi disisi lainnnya, anak-anak cacat sumbing tersebut jelas mengalami ketidaknyamanan identitas saat ditertawakan karena sumbing, seperti Ekayang menurut Anjani adalah anak yang pemalu. Tentu Eka merasa sangat tidak nyaman dengan olok-olokan temantemannya, terutama disekolah sehingga hal ini mengganggu Eka secara psikologis. Dalam hal ini, kelompok kecil masyarakat seperti teman bermain anak-anak cacat sumbing ini dapat mendorong adanya ketidaknyamanan dalam terbentuknya identitas anak-anak cacat sumbing itu sendiri. 
3. Setiap orang akan cenderung mengalami kenyamanan identitas dalam suatu lingkungan budaya yang familiar baginya dan sebaliknya akan mengalami identitas yang rentan dalam suatu lingkungan yang baru.

Keterangan pada poin dua juga berhubungan erat dengan teori negosiasi identitas yang ketiga ini yaitu anak-anak cacat sumbing ini cenderung mengalami kenyamanan identitas dalam suatu lingkungan yang familiar bagi mereka, seperti teman-teman yang sudah lama mereka kenal. Seperti pengematan yang telah dilakukan peneliti terhadap anakanak cacat sumbing di Desa Curup bahwa baik Pegar, Eka, dan Abi sangat dekat dengan lingkungan yang masyarakat di Desa Curup.

Meskipun sulit dalam memahami maksud perkataan anak-anak cacat sumbing ini, beberapa anggota masyarat di Desa Curup seperti informan kunci yang terdiri dari tetangga dan teman bermain anak-anak cacat sumbing menerima mereka dengan berusaha berkomunikasi dengan anak-anak cacat ini. Namun sebaliknya, anak-anak cacat sumbing menemui kesulitan saat bertemu dengan lingkungan baru. Tentu dalam lingkungan yang baru setiap individu harus menyesuaikan diri sesuai dengan kondisi yang ada dilingkungan tersebut. Dalam hal ini, anak- anak normal pun tentu memperoleh kesulitan dalam beradaptasi apalagi anak-anak cacat sumbing ini. Oleh karena itu, orangtua anak-anak cacat sumbing tersebut mengatakan bahwa pindah ke lingkungan yang baru belum dibutuhkan karena anak-anak merekapun masih merasa nyaman dengan perlakuan orang-orang di sekitar lingkungan saat ini. Salah satu penyebab anak-anak cacat sumbing ini belum membutuhkan untuk pindah ke lingkungan yang baru, menurut pengamatan penulis adalah bahwa cacat sumbing bisa menjadi bahan tertawaan yang membuat mereka malu bagi kelompok masyarakat di lingkungan baru. Setiap individu dalam menghadapi orang- orang baru di sekitar mereka tentu berbeda-beda, termasuk anak-anak cacat sumbing ini. Dari pernyataan informan pokok (anak-anak cacat) sangat jelas keinginan mereka mendapatkan kenyamanan saat bersamaorang- orang yang dirasa kenal dekat dengan mereka dibandingkan dengan orang-orang yang baru dikenal. Samahalnya penyampaian dari informan kunci (para orangtua) dari anak-anak cacat sumbing ini, kenyamanan dalam lingkungan yang baru belum bias dirasakan oleh anak-anak cacat sumbing karena anak- anak ini butuh waktu untuk beradapatasi.

4. Setiap orang cenderung merasakan kepercayaan identitas ketika berkomunikasi dengan orang lain yang budayanya sama atau hampir sama dan sebaliknya kegoyahan identitas manakala berkomunikasi mengenai tema-tema yang terikat oleh regulasi budaya yang berbeda darinya.

Dalam hal ini, prinsip negosiasi identitas didasari atas hubungan antar pribadi melalui kedekatan relasi yang mendukung ikatan keluarga dan persahabatan antara anak-anak cacat sumbing dengan orang-orang yang berada di sekitar mereka. Meskipun mempunyai kekurangan seperti cacat sumbing, ketiga anak ini masih mendapatkan dukungan dari orang-orang didekat mereka, sekurang-kurangnya orang tua mereka. Menurut hasil wawancara dengan tetanga anak-anak cacat sumbing ini, seperti Bapak Jarwo dan Ibu Astuti yang mengatakan bahwa orang tua Pegar dan Abi sangat sayang dengan anak-anak mereka. Namun bukan berarti mereka dimanja, jika mereka melakukan kesalahan tetap memperoleh hukuman seperti dikurung dikamar misalnya. Hal ini menggambarkan bahwa orang tua anakanak cacat ini tetap memperlakukan anakanak mereka sebagaimana anak-anak normal diperlakukan. Dalam cakupan yang lebih luas seperti anggota masyarakat di Desa Curup, anak-anak cacat sumbing ini 
pun mendapat perlakuanyang sama dengan anak-anak normal lainnya seperti diajak jalan-jalan atau bertamasya, dan bahkan diikutkan pada perlombaan contohnya menggambar dan menulis puisi.

Akan tetapi, persoalan timbul pada saat berada dilingkungan sekolah. Sebagaimana diketahui bahwa sekolah mempunyai murid- murid yang berbeda asal dan budaya. Dalam hal ini, anak-anak cacat sumbing merasa tidak percaya diri berkomunikasi dengan beberapa anak-anak yang berada di sekolah sehingga mereka tidak jarang berkelahi, seperti Pegar dan Abi yang pernah berkelahi dengan temanteman bermainnya di sekolah karena dikatai "sumbing". Persoalan ini memperlihatkan bahwa persamaan budaya yang dimiliki memberikan pengaruh besar bagi anak-anak cacat sumbing dalam berkomunikasi dengan orang-orang disekitar mereka tanpa rasa minder yang berlebihan. Sebaliknya perbedaan budaya berdampak pada berkurangnya kepercayaan diri atau kegoyahan identitas anak-anak cacat sumbing tersebut.

5. Seseorang akan cenderung merasa menjadi bagian dari kelompok bila identitas keanggotaan dari kelompok yang diharapkan member respon yang positif. Sebaliknya akan merasa berbeda/asing saat identitas keanggotaan kelompok yang diinginkan member respon yang negatif.

Prinsip ini menekankan pada kecenderungan anak-anak cacat sumbing ini merasa menjadi bagian dari kelompok bila identitas mereka keanggotaan dari kelompok yang diharapkan member respon positif. Para orang tua terkait dengan apakah orang-orang disekitar mereka memberikan respon positif terhadap keberadaan anak-anak mereka meskipun menderita bibir sumbing. Dari hasil wawancara, orangtua dari anak-anak cacat sumbing ini telah memberikan respon positif bagi anak-anak mereka dengan melakukan aktivita seperti bertamasya (jalan- jalan) dan membelikan baju baru untuk anak-anak mereka. begitu pula dengan pernyataan tetangga dan teman bermain anak-anak cacat sumbing yang berpendapat bahwa mereka tidak membeda-bedakan anak-anak cacat sumbing dalam pergaulan masyarakat di Desa Curup tersebut. Anak-anak cacat sumbing tetap menjadi bagian yang tidak dapat dipisahkan dari masyarakat Desa Curup.

Akan tetapi, subjekyang memberikan respon negatif ini adalah teman-teman bermain mereka yang sering meniru cara bicaranya. Teman-teman mereka tersebut adalah teman-teman bermain disekolah. Respon negatif berupa tindakan mengolokolokan cacat sumbing mereka menciptakan idenitas sebagai anggota kelompok masyarakat terasa asing, atau merasa terpisahkan dari anggota masyarakat yang terdiri dari anak-anak normal lainnya.

6. Seseorang akan mengharapkan koneksi antarpribadi melalui kedekatan relasi yang meaningfull (misalnya dalam situasi yang mendukung persahabatan yang akrab) dan sebaliknya akan mengalami otonomi identitas saat mereka menghadapi relasi separatis/terpisah.

Setiap individu pasti mengharapkan koneksi antar pribadi begitupun dengan anak-anak cacat sumbing di Desa Curup Kecamatan Merigi Sakti Kabupaten Bengkulu Tengah. Seperti halnya pernyataan Pegar dan Eka orang tua mereka sering membelikan baju baru dan mengajak jalan-jalan, itu merupakan suatu perwujudan (manifestasi) dukungan dari orang-orang terdekat sehingga adanya hubungan yang dekat antara orangtua dan anak.

Sebaliknya anak-anak cacat sumbing di Desa Curup Kecamatan Merigi Sakti kadang-kadang juga mengalami otonomi identitas saat mereka berkomunikasi dengan teman-teman bermain mereka, dari pernyataan Eka dan Abi seringkali temanteman mereka minta mereka mengulangi setiap kalimat yang terucap kadangkadang teman-teman mereka juga mengejek sehingga dalam situasi tersebut 
anak-anak cacat sumbing memilih untuk tidak bicara.

7. Orang akan memperoleh kestabilan identitas dalam situasi budaya yang dapat diprediksi dan akan menemukan perubahan identitas atau goncang dalam situasi-situasi budaya yang tidak diprediksi sebelumnya.

Dalam penelitian ini, orang-orang yang berada dekat dengan anak-anak cacat sumbing dianggap paling mengerti. Di sini dapat dilihat bahwa orang tua anak-anak cacat sumbings udah terbiasa dengan cara bicara anak mereka sehingga mereka mengerti dan memahami setiap ucapan anak-anak sumbing tersebut sehingg aanak-anak cacat sumbing ini memperoleh kestabilan identitas dalam situasi dirumah.

Seperti pernyataan anak-anak cacat sumbing di Desa Curup Kecamatan Merigi Sakti Kabupaten Bengkulu Tengah bahwa orang tuanya mengerti saat mereka bicara. Namun sebaliknya mereka akan merasa goncang ketika mereka berbicara oranglain minta diulang-ulang sampai berkali-kali bahkan ada makna mengejek sehingga membuat perubahan identitas mereka, seperti mereka akan menunjukan ekspresi marah ataupun menangis.

Keterangan diatas menggambarkan bahwa anak-anak cacat sumbing pada dasarnya mengerti dengan kondisi yang membuat mereka senang seperti diberikan kasih sayang, bermain bersama, dan bercanda ria dengan orang-orang terdekat mereka. Situasi-situasi semacam ini merupakan sejumlah situasi yang akan diprediksi oleh mereka. Namun ketika ada orang-orang atau teman-teman yang mengejek mereka, situasi ini menciptakan ketidakstabilan identitas mereka sebagai anggota masyarakat.

8. Dimensi budaya, personal dan keragaman situasi mempengaruhi makna interpretasi dan penilaian terhadap tematema atau identitas tersebut. Setiap budaya atau kebiasaan mempengaruhi identitas anak-anak cacat sumbing di Desa Curup
Kecamatan Merigi Sakti Kabupaten Bengkulu Tengah, seperti kebiasaan dari orang-orang didekat mereka yang selalu mendukung dan memotivasi anak-anak cacat sumbing tersebut memberikan pengaruh besar bagi mereka dalam membentuk komunikasi dengan orangorang disekitar mereka tanpa rasa minder yang berlebihan.

Merekapun ikut serta dalam kegiatan masyarakat seperti ikut perlombaan 17 Agustus. Keragaman tersebut dapat merubah isu-isu identitas mereka, dengan terlibat dalam kegiatan masyarakat anak-anak cacat sumbing berarti mampu berinteraksi sama seperti anak-anak normal lainnya walaupun mereka memiliki ketidaksempurnaan.

9. Kepuasan hasil dari negosiasi identitas meliputi rasa dimengerti, dihargai dan didukung.

Prinsip negosiasi pun meliputi rasa dimengerti, dihargai dan didukung oleh orang-orang di luar individu. Dalam penelitian ini, orang-orang yang berada dekat dengan anak-anak cacat sumbing dianggap paling mengerti, menghargai dan mendukung mereka. Orang- orang tersebut merujuk kepada orangtua atau anggota keluarga mereka.

Disini dapat dilihat bahwa kepuasan hasil dari negosiasi identitas anak-anak cacat sumbing ini bisa saja berupa kasih sayang dan perhatian khusus dari orangorang terdekat mereka terutama orang tua. Seperti pernyataan Pegar bahwa orang tuanya sering membelikan baju baru dan mengajak Ia jalan-jalan.

Pada contoh ini, membelikan baju dan mengajak jalan-jalan merupakan suatu perwujudan (manifestasi) dukungan dari orang-orang terdekat anak-anak cacat sumbing sehingga mereka memahami bahwa identitas sebagai anggota keluargadan masyarakatsangat diterima.

10. Komunikasi antarbudaya yang mindfull menekankan pentingnya penyatuan pengetahuan antar budaya, 
motivasi dan keterampilan untuk dapat berkomunikasi dengan memuaskan, tepat dan efektif.

Terbentuknya komunikasi yang baik,dalam artian bahwa informasi yang dibutuhkan dapat tersampaikan secara sempurna merupakan sasaran dari negosiasi identitas. Dalam hal ini, anakanak cacat sumbing yang memang memiliki keterbatasan dalam berbicara atau menyampaikan pesan tetap dapat berupaya optimal untuk berkomunikasi dengan baik dengan orang-orang disekitar lingkungan mereka.

Sebagaimana yang disampaikan oleh Pegar ketika ditanya mengenai apakah saat bicara dengan orang-orang disekitarnya, mereka mengerti maksud Pegar dan dengan perbedaan yang dimilikinya, apakah Ia terdorong untuk lebih terampil lagi dalam berkomunikasi dengan yang lain. Orang-orang yang berada disekitar mereka seperti teman-teman anak-anak cacat sumbing ini mampu menerima halhal yang dibicarakan oleh anak-anak cacat sumbing namun butuh waktu dan konfimasi yang terkadang berulang-ulang. Orang-orang disekitar anak-anak cacat sumbing di Desa Curup ini akan meminta mereka mengulangi apa yang mereka bicarakan sebelumnya.

Dalam hal ini, komunikasi antara anak-anak cacat sumbing dengan orangorang di sekitar mereka belum dapat berjalan secara memuaskan, tepat dan efektif. Memuaskan dalam pengertian bahwa komunikasi tersebut dapat terlaksana seperti anak-anak normal berkomunikasi, namun hal tersebut membutuhkan waktu yang cukup lama. Atau seperti pernyataan Pegar bahwa anak-anak sumbing dapat melakukan operasi bibir agar dapat berbicara dengan lebih baik.

\section{PENUTUP}

\section{Kesimpulan}

Setelah melakukan analisis data dengan menerapkan prinsip-prinsip penting teori negosiasi identitas, peneliti dapat menyimpulkan bahwa:

1. Anak-anak cacat sumbing di Desa Curup pada dasarnya mampu berkomunikasi sama seperti anak-anak normal, hanya saja anak-anak cacat sumbing mengalami sedikit kesulitan karena kekurang sempurnaan alat bicara mereka dalam menyampaikan kata-kata dengan oranglain.

2. Anak-anak cacat sumbing di Desa Curup merasa percaya diri ketika mereka bersama orang-orang terdekat mereka yang bias memahami dan mengerti mereka.

3. Kenyamanan dalam identitas anak-anak cacat sumbing hanya pada orang- orang terdekat mereka saja. Karena orang-orang terdekat mereka mengerti dan memahami mereka.

4. Ikatan keluarga dianggap oleh anakanak cacat sumbing sebagai ikatan yang mendukung identitas mereka

5. Respon positif yang diberikan oleh anggota keluarga terhadap anak-anak cacat sumbing adalah penerimaan terhadap keberadaan mereka, tetapi respon negative ditunjukkan oleh teman-teman bermain yang meniru cara bicara mereka seperti seorang yang sumbing.

6. Anak-anak cacat sumbing di Desa Curup ini memperoleh dukungan dari orang-orang terdekat sehingga adanya hubungan yang dekatantaraorang tua dan anaksehingga hal ini membentuk kedekatan relasi yang mindful.

7. Kestabilan identitas anak-anak sumbing sebagai anggota masyarakat dapat terjadi pada saat orangtua mampu mengerti kebutuhan mereka, namun identitas tersebut goyah saat terdapat orang-orang yang mengejek mereka

8. Keikutsertaan mereka dalam aktivitas budaya seperti lomba perayaan 17 Agustus-an membuat identitas mereka dapat terbentuk

9. Kepuasan hasil dari negosiasi identitas anak-anak cacat sumbing di Desa Curup ini berupa kasih sayang dan perhatian 
khusus dari orang-orang terdekat mereka terutama orangtua.

10. Komunikasi antara anak-anak cacat sumbing dengan orang-orang disekitar mereka belum dapat berjalan secara memuaskan, tepat dan efektif karena dalam penyampaian pesan kurang optimal.

\section{Saran}

Dari hasil pembahasan dan kesimpulan penelitian ini, peneliti menyarankan:

1. Diharapkan seluruh masyarakat dapat menerima anak yang berkebutuhan khusus (cacat sumbing) di Desa Curup Kecamatan Merigi Sakti Kabupaten Bengkulu Tengah. 2. Diharapkan ada pengertian dan rasa saling menghargai diantara orang-orang disekitar dengan anak cacat sumbing, karena mereka berhak mendapatkan perlakuan yang sama.

3. Bagi peneliti untuk selanjutnya dapat menerapkan teori negosiasi ini lebih mendalam lagi oleh mahasiswa/mahasiswi yang mengambil jurusan ilmu-ilmu sosial.

\section{DAFTAR PUSTAKA}

Bungin,Burhan. 2007. Penelitian Kualitatif, Komunikasi, Ekonomi, Kebijakan, Publik, dan Ilmu Sosial Lainnya. Jakarta: Putra Grafika.

Gudykunts, William B. 2001. Handbook of International and Intercultural Communication Second Edition. California: SAGE Publication.

Moleong, Lexy. 2002. Metode Penelitian Kualitatif. Bandung: P.T. Remaja Rosdakarya.

Nazir, Moh. 2003. Metode Penelitian. Jakarta: Ghalia Indonesia.

Purwadi. 2004. Proses Pembentukan Identitas Diri Remaja. Humanitas: Indonesian Psychological Journal.

Rakhmat, Jalaluluddin. 2004. Metode Penelitian Komunikasi. Bandung: PT. Remaja Rosdakarya.

Sekaran, Uma. 2006. Metodologi Penelitian Untuk Bisnis. Jakarta: Salemba Empat.
Stuart, GW. 2002. Keperawatan Jiwa. (Terjemahan Ramona Egi). Jakarta: EGC. Sugiyono. 2005. Metode Penelitian Kuantitatif. Bandung: Alfabeta.

Sugiyono. 2013. Metode Penelitian Kuantitatif, Kualitatif, dan $R \& D$. Bandung: CV. Alfabeta.

Suyatno, Bagong. 2005. Metode Penelitian Sosial: Berbagai Alternatif Pendekatan. Jakarta: Prenada Media.

Setiawan,Farhan.2011.Skripsi:"PolaPenge mbanganAnakAutisdiYayasanSayan gIbu (YSI)Yogyakarta”.Yogyakarta: Universitas Sunan Kalijaga.

Mayyesa, $\quad$ Maya. 2012. Skripsi:"Komunikasi Antar Pribadi dan KepribadianAnak-Anak Cacat".Medan: Universitas Sumatera Utara.

Pratiwi,Dini. 2012. Skripsi: Komunikasi Interpersonal Orang Tua dalam Meningkatkan Rasa Percaya Diri Pada Anak Tuna Daksa. Jakarta: Universitas Gunadharma.

http://www. dokter sehat. com/ apadefinisi-sumbing,diunduh pada jam 13.00WIB, Tgl 22/02/2016 